\title{
Sartre e o Humanismo Racista Europeu: uma leitura sartriana de Frantz Fanon
}

MARCO ANTONIO ARANTES"

\section{Resumo}

Centrado no livro de Sartre, "Colonialismo e Neocolonialismo - Situações $V^{\prime \prime}$, e no seu prefácio escrito para o livro Les Dammés de La Terre, de Frantz Fanon, o presente artigo propõe percorrer algumas considerações sartrianas a respeito de Fanon e o colonialismo francês na Argélia, tendo como pano de fundo a complexidade das relações sociais em países colonizados. Como representantes do pensamento anticolonial e críticos das alienações geradas pelo colonialismo, Sartre e Fanon elaboraram críticas radicais sobre as estratégias de violência, subordinação e desumanização que atingiram o colonizado africano, instigados pela reconstrução social com o uso da violência, buscando-se assim um novo homem em sua verdadeira humanidade.

Palavras-chave: Neocolonialismo. Imperialismo. Argélia. Violência.

\footnotetext{
* Professor Adjunto do Curso de Ciências Sociais da Universidade do Oeste do Paraná - Campus de Toledo/PR.
} 


\section{Considerações Iniciais}

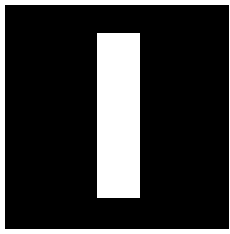

solamento, solidão, ansiedade e angústia, nas palavras do amigo e biógrafo John Gerassi, permearam a existência tumultuada do filósofo Jean Paul Sartre, associados ao brilhantismo, vivacidade e audácia de uma inteligência que buscou rever nas relações sujeito/objeto suas dicotomias, buscando atingir a compreensão do real. Em 1933-1934, ele escreve A Transcendência do Ego, apoiado em Husserl, para quem a consciência significava sempre a consciência de um objeto que não tinha conteúdo em si mesmo, postulando a existência de um ego transcendental "por trás" da consciência, como possibilidade de estudo do objeto separado do eu que o via e/ou conhecia. Em outras palavras, trata-se de pôr o mundo entre parênteses para estudá-lo isoladamente. Já, para Sartre, o ego está do lado de fora, está no mundo: Não é em algum retiro que nos descobrimos a nós mesmos: é na estrada, na cidade, no meio da multidão, coisa entre coisas, homem entre homens (Geraasi, 1990, p. 123).

Mas as preocupações sociais que marcariam seu futuro não afloram nos primeiros anos que antecedem ao início da Segunda Guerra Mundial. A Transcendência do Ego será escrita em Berlim, neste período, sem que a chegada do nazi-fascismo, com suas comemorações triunfais, viesse atrapalhá-lo. Será necessário um tempo maior para que sua prisão e posterior participação na Resistência Francesa possam operar as mudanças que as décadas de 1950/1960 irão conhecer. Vale ressaltar ainda que, se a $2^{a}$ Guerra, o colaboracionismo francês, o Partido Comunista, o anti-semitismo, a morte de colegas e amigos judeus, entre eles Paul Nizan, traições, delações e alienações são partes de um motor que fez desabrochar o filósofo odiado do seu século, desde os tempos da École Normal, Sartre já manifestava decepção e descrédito pela burguesia que freqüentava o 
mundo intelectual e artístico francês. Fez inimigos, com destaque para Raymond Aron, e rompeu amizades preciosas, entre elas Merlau Ponty e Albert Camus.

Em Que é a Literatura? de 1947, esboça o perfil deste universo, olhando para o curso de três gerações. A primeira, que começou a produzir antes de 1914, é a que termina quando Sartre começa. Seus representantes maiores, André Gide e Marcel Proust, são partes de um grupo que, por razões de comprometimento com a classe de onde provêm e por não viverem exclusivamente de seu trabalho, acham-se compelidos a salvar a burguesia. Neste processo, salvam-se a si próprios. A segunda geração seria aquela que já é adulta em 1918, da qual se sobressaem os surrealistas, por quem Sartre manifesta profundo desagrado, particularmente Breton e Salvador Dali. Dissolver a subjetividade mediante o aniquilamento das distinções entre vida consciente/inconsciente, sonho/vigília, escapando à consciência de si e de sua situação no mundo, e implodir a objetividade anulando objetos-testemunhas seriam as premissas chaves do surrealismo. Em suas palavras, é melhor chamá-lo de Impossível, ou se se preferir, de ponto imaginário onde se confundem o sonho e a vigília, o real e fictício, o subjetivo e o objetivo (Sartre, 1989, p. 138).

Por fim, a geração de Sartre. Pressionada e já situada historicamente pelos 22 anos que separam as duas guerras, eles simulam um clima superficial de paz, que esconde o que está por vir, até porque os primeiros momentos da ocupação alemã não alteram substancialmente a vida dos franceses, em particular, dos parisienses. Como dissemos, é depois de sua prisão e fuga de um campo de concentração que ele passa a tomar posições políticas mais definidas e a se opor aos desmandos dos opressores. Esse posicionamento se reflete nas palavras de Sartre: 
De repente nos sentimos bruscamente situados: sobrevoar os fatos, como gostavam de fazer nossos predecessores, tornou-se impossível; havia uma aventura coletiva que se desenhava no porvir e era a nossa aventura, a que permitiria mais tarde datar a nossa geração, com os seus Ariéis e os seus Calibãs; algo nos aguardava nas sombras do futuro, algo que nos revelaria a nós mesmos, talvez na iluminação de um derradeiro instante antes de nos aniquilar;o segredo de nossos gestos e de nossas determinações mais íntimas estava diante de nós, na catástrofe a que nossos homens iriam vincular-se (Sartre, 1989, p. 158).

Logo em seguida, funda o grupo Socialismo e Liberdade, com o propósito de colaborar com a Resistência e, em 1945, cria a revista Temps Modernes. Obrigada a fazer uma literatura de historicidade, contrariamente a escrever sobre a dor que redime ou a partilhar de uma hipócrita tolerância expressa na democracia, que terminava por tolerar a intolerância além de não distinguir as noções de Bem e Mal, esta geração se viu abandonada, inclusive pela dialética marxista. Restava, para ela, o processo histórico. No entanto, será na intersecção entre Literatura e Filosofia, segundo Mészáros, que ele encontra o método pelo qual se destaca o propósito de mostrar que a razão analítica é insuficiente contra o poder dos mitos e dos interesses. Não se substitui a realidade existente, firmemente enraizada e 'positiva' (no sentido hegeliano), pela mera negatividade de dissecção conceptual. Para que a arma da crítica possa ter êxito, precisa estar à altura do poder evocativo dos objetos a que se opõe (Mészáros, 1991, pp. 20-21). A partir daí, a idéia de engajamento se constrói, porque compete ao escritor engajado a dissolução dos mitos e fetiches, num banho de ácido crítico.

Para não nos alongarmos em excesso nestas considerações iniciais, resta o que caracteriza por inteiro a obra de Jean Paul Sartre. Por meio de três grandes obras literárias que compõem os Caminhos da Liberdade e de personagens como Mathieu, Daniel e Jacques, assentam-se as bases de 
sua filosofia existencialista. Para Marilena Chauí, no primeiro deles, A Idade da Razão (1945), estão presentes os domínios da história e da política com o predomínio dos problemas individuais. O segundo Sursis, também de 1945, demonstra que os projetos individuais são determinados pela história, sendo desprovido de sentido capturar a liberdade no plano pessoal: a liberdade é sempre vivida em situação e realizada no engajamento de projetos voltados para interesses humanos comunitários (Chauí, 1978, p. XII-XIII). No último livro da trilogia, Com a Morte na Alma, de 1949, o personagem Mathieu nos remete aos dilemas do engajamento político sem qualquer objetividade. Em resumo, e seguindo o raciocínio de Chauí, os pressupostos da filosofia existencialista situam-se na ausência de Deus e na posição alcançada pelo homem como criador de seus próprios valores. Trata-se, portanto, de uma forma de humanismo radical. Sartre ainda seguiria em frente. A publicação de "O Existencialismo é um Humanismo", em 1946, poderia ser tomada como marco, significando um momento de reordenação do universo intelectual do filósofo.

\section{A Filosofia do Engajamento}

Há algo inquietante e provocador, algo prestes a explodir e submergir na obra filosófica de Jean Paul Sartre. Sua filosofia, definida no opúsculo "O Existencialismo é um Humanismo" como existencialismo ateu, consiste na idéia da precedência da existência sobre a essência, uma doutrina na qual a verdade e a ação estariam implicadas na subjetividade humana e no meio pelo qual se descobre, surge, define e lança o homem para um futuro.

Há uma contínua e necessária interação entre os homens. Sartre fala, aqui, em responsabilidade - de um engagement que implica assumir uma posição diante de uma ação concreta perante nós mesmos e os 
outros. Não é em Deus que encontraremos essa verdade, mas na subjetividade individual descoberta no âmbito da liberdade, pois, para Sartre, ao querermos a liberdade, descobrimos que ela depende inteiramente da liberdade dos outros, e que a liberdade dos outros depende da nossa (Sartre, 1979, p. 25). É esse compromisso com a liberdade, em que cada homem realiza um tipo de humanidade, que Sartre assume uma responsabilidade frente aos povos oprimidos durante o processo de colonização e partilha do mundo pelos países europeus. Portanto, serve-se agora do existencialismo como doutrina da ação.

Em 1946, ocorre uma mudança na rota operada por Sartre, já que o mundo ao seu redor encontra-se em ebulição. Ebulição que vinha diretamente das Colônias. Em suas considerações sobre o Colonialismo e o Neocolonialismo, as palavras do filósofo foram projetadas para a ação política e revolucionária, para a recuperação dos povos oprimidos pelo colonizador, voltando-se contra os homens com o verbo na língua, aqueles que obrigavam os habitantes de uma colônia a se vestirem como europeus, marcando homens colonizados com ferro em brasa como gado, enjaulando negros como animais selvagens, silenciando-os com mutilações, torturas e mordaças nas bocas. A sua visão sobre o racismo imperialista europeu de conquistas, guerras e dominações coloniais, sobre as práticas de intolerância, exploração e humilhação dos povos subjugados, conjuntamente com sua crítica sobre uma forma nacional francesa de tradições racistas, que se desdobrou na colonização, tentava convencer outros intelectuais franceses de que o neocolonialismo era uma realidade que não se podia tratar com indiferença.

Para ele, o colonizador que escraviza outro homem como se fosse um pedaço de carvão, facilmente substituível por um sangue novo negro, carrega em seu ser uma ânsia de explorar e espoliar as riquezas naturais, sem limites. Para estes homens, o importante era espoliar as riquezas tropicais da colônia para serem transformadas em manufaturas na metrópole, 
não importando o homem cultural, dotado de sentimentos, de língua, de religiosidade, mas apenas sua força, sua mão-de-obra a serviço da nação colonizadora. Francisco Iglésias, referindo-se ao alargamento do mundo pelas descobertas marítimas na Idade Média, salienta que houve uma

ampliação do horizonte geográfico mais que do horizonte histórico, uma vez que tais descobertas não importavam em incorporação de outros povos: tomava-se conhecimento de que o mundo era mais amplo, explorava-se economicamente, na medida do possível, o que se revelara. E era só. Esses continentes e ilhas pouco mais sugeriam. Seus habitantes, enquanto homens, só contavam para alguns poucos abnegados religiosos. No mais, eram povos exóticos, com a atenção que sempre merecem os exotismos (Iglésias, 1971, p. 23).

É com a presença efetiva de parte de sua força armada que o colonizador infere contraditoriamente seu discurso "civilizador", instaurando o domínio e a exploração sobre a grande maioria da população, com base no uso da força, na imposição cultural, na inquirição de elementos exóticos e na intimidação pelo fogo lançado de um fuzil, símbolo maior de uma suposta superioridade científica, tecnológica, econômica e cultural. Usa-se a força como instrumento de superioridade cultural, para mudar velhos padrões de uma sociedade tribal e para impor o trabalho forçado. Eles, os nativos africanos, diziam os colonizadores evolucionistas, são os ditos animais em estado de evolução, são os seres que um dia fomos, no passado.

O projeto colonizador, essa máquina sanguinária e espoliadora, precisava de uma máscara civilizadora para seguir adiante com o seu projeto dito benfeitor: índios, negros, árabes, indianos, angolanos, argelianos não poderiam medir forças com essas "raças gigantes" que inventam metraIhadoras e espalham vírus capazes de dizimar indígenas como moscas. Colonizar significaria também "civilizar" povos ignorantes sem cultura, moral, literatura, indústrias, comércio, ciência e religião. O estadista Bismark afirmava que a Europa tinha a missão de levar a paz aos bárbaros, 
pois ela deveria exterminar a escravidão, interditar o canibalismo, sacrifícios humanos, a incineração das viúvas, levar práticas modernas de combate às epidemias, à doença e à fome (Linhares, 1981, p. 47). Este aspecto justificaria essa máquina espoliadora, mercantilista nos primórdios, e expansionista e capitalista em um segundo momento, acompanhada de um sistema de trocas unilateral, que se autodenominava civilizadora e não destrutiva, mas que era cega às conseqüências funestas de uma revanche dos mesmos colonizados quando conscientes de sua condição alienada. O que até então era considerado irredutível, oposto e heterogêneo na dinâmica cultural, se submeteria à convivência na tolerância imposta pelo uso da força. O escritor George Orwell, em seu romance autobiográfico "Dias na Birmânia" (Burmese Days,), dizia que os ingleses não se preocupavam com as provas, principalmente quando um homem de cara preta fosse suspeito de um crime. Nesse caso, a suspeita já era a prova de culpa de um nativo e o enforcamento era dado como certo (Orwell, 1983).

Orwell havia percebido desde cedo a necessidade dos ingleses de se diferenciarem ao máximo dos nativos subjugados. No entanto, mesmo tendo conhecimento da máquina de espoliação e de se colocar contra a opressão britânica, o próprio Orwell nunca conseguiu explicar a decisão de tornar-se um dos responsáveis pela segurança do Império Colonial na Índia. Entretanto, seu período como policial ajudaria a explicar suas atitudes posteriores (Neto, 1984).

Por fim, sua aproximação com o marxismo o leva, em primeiro lugar, a priorizar a idéia da realização da filosofia, em termos de uma ação sobre o mundo e, em segundo, inspirado pelo pensamento de Fanon e pelos movimentos de libertação nacional argelinos, a considerar a violência como intrínseca e necessária à conquista da liberdade. O sentido do marxismo ecoa resquícios do racionalismo kantiano e do racionalismo cartesiano, constituindo-se, nestes termos, na realização prática da pró- 
pria filosofia, quando, como dizia Marx, ela torna-se mundo, encaminhada para a expressão de uma determinada corrente política. Em outros termos, longe da filosofia contemplativa, Sartre falava de filosofia e filósofos comprometidos com a ação política e a transformação do homem. Acresce que, para ele, as situações dadas no conjunto do mundo irão determinar a morte de uma corrente filosófica. No caso da filosofia de Marx, por exemplo, somente após a destruição do mesmo sistema econômico capitalista que a engendrou, somente depois que o regime político e os homens se modificassem, o marxismo seria superado. Marx afirmava: ou o socialismo ou a barbárie, vale dizer que, ou ultrapassamos as contradições do capitalismo ou seremos constrangidos a trabalhar por exploração. Mesmo considerando as modificações experimentadas pelo capitalismo, Sartre, ainda na década de 1960, via no marxismo uma filosofia insuperável. Após a publicação de "O Existencialismo é um Humanismo", será necessário posicionar-se frente à independência das Colônias, tomar partido diante dos movimentos de libertação nacional e dos novos Estados que surgem a partir de 1945. Tarefa difícil, porque uma incomensurável remodelação do mapa-múndi colocará na ordem do dia as oposições colonizador/colonizado, branco/negro, cristão/não cristão, ocidental/não ocidental, obrigando os intelectuais de maneira geral, e Sartre em particular, a debruçarem-se sobre este Outro que caminha em direção às Metrópoles.

\section{Pensamento e Ação Anti-Coloniais}

Em que pese o objetivo da expansão ocidental sobre a África e a Ásia estar voltado para a espoliação e dominação das Colônias, os colonialismos apontam características que os diferenciam entre si. O crítico literário Edward Said, em "Cultura e Imperialismo", pensa na relação entre territórios sobrepostos e histórias entrelaçadas como elementos chaves na 
escalada dos Impérios: a história e a geografia são reordenadas e reescritas nas Metrópoles, ao mesmo tempo em que a música, a poesia, a prosa e as ciências recriam o espaço conquistado, tornando o duplo Colônia/ Colonizado portador de características justificadoras da dominação. Os romances coloniais ingleses, através de Joseph Conrad, George Orwell, E.M.Forster, Edward Kipling, entre outros, revelam, como faz Conrad em Heart of Darkness, que as trevas devem ser iluminadas, o vazio da selva preenchido e o mundo permanentemente feito e refeito através da missão expansionista e "civilizadora" de Kutz e Marlow no coração da África. Evidentemente por estar à frente de seu tempo, para Conrad

o que se afigura estável e seguro - o policial na esquina, por exemplo - é apenas um pouquinho mais seguro do que os homens brancos na selva e requer a mesma vitória constante (mas precária) sobre as trevas, que tudo invadem e que, no final da narrativa, se revelam iguais, seja em Londres ou na África (Said, 1993, p. 63).

Se as representações do Ocidente sobre as culturas estrangeiras serviram aos propósitos da empresa colonial, nas palavras de Said, o colonialismo francês, embutindo a idéia de prestígio e impulsionado pela vocação superior francesa, teve por alvo a assimilação. Trata-se não apenas de civilizar, mas de "afrancesar" seus colonos.

Em, "Orfeu Negro", introdução à Anthologie de la nouvelle poésie nègre et malgachede Léopold Sedar Senghor, Sartre denuncia o projeto de aniquilamento das culturas tradicionais, tendo a língua francesa como instrumento mais potente. Estabelecendo contato com a palavra dos poetas africanos e antilhanos que residiam em Paris, ele dirá que o poema não se destina ao público francês e que não há nisso razão para surpresas. Embora escrito em francês, é a palavra nègre que realça a negrura da noite e a beleza da alma e da cor, a volta à África ancestral e os sentidos da negritude tomada como liberdade. Desumanizado enquanto homem negro, como 
nativo colonizado ou negro deportado, o encontro com sua humanidade perdida só será possível quando a palavra preto for recuperada diante do branco e quando for reconhecido como homem preto que é. Finalmente, por ser oprimido em sua raça, é dela que deve tomar consciência. Um judeu branco entre os brancos pode negar que seja judeu, declarar-se homem entre homens. O negro não pode negar que seja negro ou reclamar para si esta abstrata humanidade incolor: ele é preto (Sartre, 1968, p. 94).

Sartre não estava sozinho nessa luta e os primeiros sinais de que o embate anticolonial estava em gestação encontram-se na própria França. Na década anterior, precisamente a 10 de junho de 1932, é lançado em Paris o único número da revista Legitime Défense. Com tom de manifesto, seus autores são estudantes martinicanos, entre 20 e 23 anos, fortemente influenciados pelo movimento surrealista e que encontram no mundo capitalista, cristão e burguês o alvo de críticas implacáveis. O ano de 1935 marca o aparecimento de L'Etudiant Noir "jornal corporativo e de combate", nas palavras de Damas, sob a direção de Léopold Sedar Senghor, do Senegal, Aimé Césaire, da Martinica, e do próprio Leon Damas, da Guiana Francesa; e,finalmente, em 1938, o conceito de negritude ${ }^{1}$ encontra-

1 Foi, provavelmente, a partir dos anos 60 do século XX que a palavra negritude passou a figurar os dicionários da língua portuguesa, vinda do francês - négritude, com uso já comum, nesse idioma, desde a década dos 30, quando escritores negros nascidos em colônias da França,usando-o como sua segunda língua, criaram-na e passaram a utilizá-la para exprimir algo novo que sentiam sem que houvessem antes encontrado termo apropriado para defini-lo. A negritude, considerada em sua essência, não nasceu, contudo, na Europa, mas em terras da América, talvez sob a inspiração do movimento New Negro, surgido dos Estados Unidos, em começos deste século, do qual participaram grandes poetas negros norte-americanos como Langston Hughes, Countee Lee, Jean Toomer e Claude McKay; todos com grande influência sobre a obra dos poetas francófonos da região das Antilhas e do Caribe, em especial sobre a de Aimé Césaire, da Martinica, e a de Léon-Gontran Damas, da Guiana. Foi, portanto, através de autores franceses da América, que chegou ao mundo europeu a palavra négritude, usada, a partir de um certo momento, por alguns intelectuais negros, como estandarte, bandeira de luta, selo de identidade étnica, sinal do orgulho que sentiam tanto por serem negros, como pelas suas origens. Waldir Freitas Oliveira. Leopold Sedar Senghor e a Negritude - Revista AfroÁsia 25-26 (2001). p. 409-410 
se pronto para vir a público. Dois seriam seus artífices: de um lado, o ensaio de Damas, Retour de Guyane, rejeitando firmemente a política colonial de assimilação e enfatizando a permanência em terras americanas das tradições africanas e, de outro, o poema de Césaire, Cahier d'un retour au pays natal, publicado em 1939.

A palavra nègre será invertida, para reivindicar a busca de raízes africanas e a construção de uma nova identidade. Em que pese a influência difusa e controvertida do conceito, a negritude não tem a mesma compreensão, seja no Continente ou na Diáspora, sendo preferível pensá-la no plural. Por fim, em dezembro de 1947, e já com objetivos distintos, simultaneamente em Dakar e Paris, sai o 1o número de Présence Africaine. Fundada por Alioune Diop, ela pretende não apenas ser um órgão oficial dos países de língua francesa, mas tornar-se representante de toda África. Présence Africaine, ao lado do prestígio de Senghor e comemorada pela intelectualidade francesa, inclusive por Sartre, caracterizou-se pelo tom moderado e "respeitoso" de seus colaboradores africanos, segundo Diva Damato, constituindo-se em referência obrigatória para quem queira acompanhar a trajetória posterior da negritude (Damato, 1983, p. 112). Por fim, indo um pouco além, restariam dois nomes chaves do contexto anticolonial francês: Albert Memmi e Frantz Fanon.

Desnecessário lembrar o papel exercido por eles sobre o pensamento sartriano. O primeiro, por desvendar conteúdos e formas de ser e agir da colonização; e, o segundo, não apenas pela contribuição teórica frente ao processo de libertação da Argélia, mas igualmente por sua militância política. Não seria demais ressaltar, também, que nos encontramos nos limites do tema colonialismo/neocolonialismo, este último entendido aqui como uma etapa posterior ao colonialismo tradicional, no qual o colonizado procura se reafirmar contraditoriamente em relação ao colonizador. Portrait du Colonisé Précédé du Portrait du Colonisateur (Retra- 
to do Colonizado Precedido pelo Retrato do Colonizador), publicado em 1957, tornou-se a obra mais conhecida de Albert Memmi, hoje professor emérito da Universidade de Paris. No entanto, sua produção inclui ainda poesias e ensaios, com destaque para Portrait d'un Juif, de 1969, Le Racisme, de 1982, e, mais recentemente, Retrato do descolonizado árabe-mulçumano e de alguns outros, de 2004. Merecedor de um estudo de Sartre no volume VII de Situations, Memmi é um intelectual que testemunhou a experiência dramática da colonização não como um observador externo, mas como um colonizado que viveu na pele os conflitos e as contradições do processo colonial. Exemplo vivo de um intelectual capaz de falar de si mesmo para conscientizar os outros povos dos problemas do colonialismo, interiorizando os conflitos sociais para projetá-lo em uma teoria revolucionária, é também através dele que Sartre internaliza a idéia de revolta do colonizado frente à assimilação impossível no processo colonial. Afinal Memmi perguntava-se: como sair da condição colonial

a não ser pela ruptura, pelo estouro, cada dia mais explosivo, desse círculo infernal? A situação colonial, por sua própria fatalidade interior, convoca à revolta. Pois a condição colonial não pode ser suportada: qual uma golilha de ferro deve ser quebrada (Memmi, 1977, p. 112).

Já "Os Condenados da Terra" (Les Dammés de La Terre, de Frantz Fanon, foi uma obra traduzida para 15 idiomas e teve um destino excepcional, servindo como referência e inspiração para muitos intelectuais anticolonialistas revolucionários como Sartre, que, no intuito de criar um novo homem livre, mobilizaram parte considerável da juventude e da intelectualidade francesas no combate ao colonialismo e suas tradições esterilizantes. Intelectual/militante, cujo testemunho até os dias de hoje inspira aqueles que se preocuparam com os destinos do continente africano, Fanon personaliza um dos momentos mais importantes da história, na segunda metade do século XX. Mas quem foi exatamente esse intelectual 
caribenho anti-imperialista, que de maneira direta e indireta exerceu influência na África, na América Latina, na esquerda negra americana dos anos de 1960, sobretudo entre os black panthers, e era admirado pelo cineasta Glauber Rocha, o qual,na sua estadia na França, Ihe dedicou o artigo "Autocrítico de um Condenado na Terra"? Frantz Fanon nasceu no Forte da França, na Martinica, em 1925, ilha que se tornou possessão francesa em 1635, e faleceu de leucemia em dezembro de 1961, no mesmo ano da primeira edição francesa de Les Dammés de La Terre. Escritor, médico e psicanalista, alistouse na segunda guerra mundial com pouco mais de 18 anos de idade, mas retornou à Martinica depois de ter-se ferido durante a campanha da França, o que the rendeu uma condecoração com a "Cruz da Guerra", dada pelo coronel Raoul Salan. Dois anos depois, inscreve-se no curso de psiquiatria da Faculdade de Medicina de Lyon, na França, onde adquire grande parte de sua formação intelectual, alternando seus estudos de medicina com leituras filosóficas e literárias, que incluíam autores como Heidegger, Sartre, Lênin, Husserl, Marx, Hegel, Merleau-Ponty, entre outros.

Todos esses fatos marcam o início de sua experiência colonial vivendo numa Argélia ocupada pela França, que se enriquecia com as importações e as exportações, e era mais conhecida pela "sovinice" da administração metropolitana, o que possibilitava uma relativa independência frente ao Império Francês "que nada dispendia nas colônias, exigindo que estas se autofinanciassem, e outra dizia respeito aos investimentos privados franceses que eram, de preferência, canalizados para empréstimos externos, quase nada aplicando nas áreas coloniais (Linhares, 1981, p. 43). Em 1953, sua trajetória ganha novos contornos, quando é enviado para Blida, na Argélia, para exercer a função de médico-chefe do Hospital Psiquiátrico local. Em 1955, com 30 anos, poucos meses depois de começar os movimentos de insurreição, por intermédio de um médico, engajase na F.L.N (Frente de Libertação Nacional), tornando pública sua causa 
a favor da independência argelina. Como figura emblemática e testemunhal de uma situação colonial opressiva, renuncia ao seu cargo em 1956, alegando em carta ao ministro residente a incompatibilidade entre sua atividade de médico e as condições imperantes de miséria e exploração a que estava submetido o país. A ruptura com o sistema colonial marca o início de seu engajamento, na forma de apoio psiquiátrico, na policlínica Charles-Nicolle de Túnis. Em 1958, como colaborador da imprensa de resistência algeriana, chega a exercer o cargo de Ministro da Informação no Governo Provisório da República Argelina e de delegado do Congresso Pan-Africano de Accra, em Gana.

Torna-se, a partir de então, conhecido na França e nos meios políticos da África, como um intelectual engajado no processo de independência. A maior parte dos seus escritos acha-se reunida na obra póstuma "Para a Revolução Francesa" (Pour la Révolution Africaine, Maspero, 1964), muito embora a totalidade de seu pensamento esteja em "Os Condenados da Terra". Não se trata de uma obra pioneira no tema, pois, como vimos anteriormente, a precursora Cahier d'un retour au Pays Natal, de Césaire - elogiada pelo surrealista André Breton, entre outros - já havia sido publicada antes da segunda guerra mundial. É dela que Fanon extrai uma página emblemática sobre a condição humilhante dos colonizados: Meu sobrenome: ofendido, meu nome: humilhado, meu estado civil: a rebeldia, minha idade: a idade da pedra (Aimé Césaire apud Fanon, 2001, p. 77).

Finalmente, no entender de Sartre, a obra de Fanon não dissimula as fraquezas, as discórdias e as mistificações do colonizado subjugado. Seu mérito está em desmontar as táticas do colonialismo, ensinando os povos desumanizados pelo colonizador a superar a complexidade e as contradições das relações sociais internas que movem a máquina colonial. Na sua obra, fica claro que é o racista que cria a inferioridade, sendo a discriminação racial o alicerce da instituição colonial. Em sua linguagem revolu- 
cionária, a luta pela libertação significaria romper e desvendar os grilhões dos mecanismos de alienação que prendem o colonizado ao colonizador e que implicavam em despersonalização, humilhação e inferioridade permanentes do colonizado, acautelando seus leitores

contra as alienações mais perigosas; o líder, o culto da personalidade, a cultura ocidental e, também, o retorno do longínquo passado da cultura africana; a verdadeira cultura é a Revolução; isso quer dizer que ela se forja a quente. Fanon fala em voz alta; nós, os europeus, podemos ouvi-lo; a prova é que temos nas mãos este livro (Sartre, 1979, p. 7).

\section{Contestação e Revolta: a força de "Os Condenados da Terra"}

Se for verdade que, com a presença efetiva, o colonizador infere contraditoriamente seu discurso "civilizador", instaurando o domínio e a exploração à grande maioria da população com base no uso da força, na imposição cultural de mãos dadas com o racismo, na inquirição de elementos exóticos e na intimidação pelo fogo lançado de um fuzil, símbolo maior de uma suposta superioridade científica, tecnológica, econômica e cultural, também pode-se considerar como verdade que contestação e revolta fazem e fizeram parte da história/geografia das sociedades dominados pelos países ocidentais. Trata-se de conferirIhes historicidade que até bem pouco Ihes fora negada. O colonialismo, portanto, não é simples despossessão, mas também humilhação, ofensa, atentado contra o ser. (Chêtelet, 1985, p. 285)

Uma breve digressão aponta que a transformação das sociedades tradicionais, para nos reportarmos a Georges Balandier, vem associada às lutas e movimentos de independência nacionais. São transições que ainda não se realizaram suficientemente e que, ao mesmo tempo, não foram 
capazes de criar legados satisfatórios às gerações futuras. São as inconstâncias políticas e sociais e a miserabilidade em que se encontra o Continente africano que tornam os dilemas das sociedades pós-coloniais, dilemas do nosso tempo. Por outro lado, a descolonização e as dimensões assumidas pelo que se conhece como pós-colonial põem em evidência a obrigação de olhar a mundialização para além de suas possibilidades e virtualidades. Em outras palavras, o passado recente ainda se reflete no presente e obriga que as ex-metrópoles tenham, por exemplo, uma resposta efetiva à onda migratória que invade a Europa. Dizer que ela não traz uma série de problemas seria hipocrisia; mas não admitir que países como Inglaterra, França e Bélgica, para citar apenas alguns, revelaram-se inaptos e, muitas vezes, inconseqüentes na condução dos processos de transição e nos diálogos com os representantes dos movimentos de libertação nacional seria igualmente uma hipocrisia. São considerações que nos remetem à atualidade do tema.

Voltando ao caso específico da Argélia, onde estão envolvidos, além de Sartre, nomes do universo filosófico francês como Albert Camus, ao lado de artistas, intelectuais e estudantes negros como Franz Fanon, que, como vimos, irão lançar sobre a Metrópole as primeiras luzes sobre a realidade das colônias, também estão em debate as posições que cada um dos lados assume. Sartre segue sua linha de reflexão e situa-se favoravelmente aos levantes, às contestações, à revolução, apoiando firmemente o uso da força e da violência como formas de ação política, afirmando que a missão de Fanon não foi apenas descrever uma situação histórica, mas conduzir os povos colonizados ao caminho de uma revolução. São as discórdias e os particularismos entre os povos africanos que ele identifica como um dos maiores inimigos da revolução. Nesse ponto, portanto, a defesa da violência no processo revolucionário de libertação colonial, constitui o ponto germinal da crítica sartriana ao humanismo europeu, delineada posteriormente em suas reflexões sobre a violência. 
Segundo ele, o proletariado urbano é inútil, atém-se aos seus próprios interesses e constitui uma força conservadora e antirrevolucionária, já que a verdadeira revolução deve começar no lumpemproletariado agrário, menos vulnerável às influências maléficas da metrópole. Fanon, aqui, rompe com a teoria leninista sobre o papel do partido revolucionário, centrada na imagem de um líder que cultua sua imagem, a seu ver incompatível com o processo de revolução anticolonialista. Contrariamente, para Sartre, alienação e liberdade não são conceitos contraditórios. Um homem só pode se alienar quando está livre e isto ocorre com os operários, livres para vender a força de trabalho, livres para serem explorados. Quanto ao colonizado, a lógica se inverte. Não há contrato, apenas opressão e violência colonial. O processo é de desumanização e o colonizador escraviza, porque não considera o outro como seu semelhante, mas como um animal. As tradições culturais são engolidas pela cultura do colonizador. Nada é poupado, nem mesmo a língua, a religião, seus mais singelos hábitos. A fadiga pelo trabaIho incessante leva-os ao embrutecimento da alma. As relações humanas ficam cada vez mais complexas, a memória cultural se distancia, e o colonizado começa a acreditar que ele é de fato um vagabundo, um preguiçoso, um ladrão. A ordem é negar a si mesmo, da ponta dos pés ao último fio de cabelo convencer-se de que nunca foi um ser humano.

Enquanto Sartre se apoiava, sobretudo, nos escritos de Marx, para formular sua teoria revolucionária, principalmente nos contidos no "O Manifesto Comunista", Fanon preferia seguir os ensinamentos do sindicalista francês Georges Sorel, autor de "Reflexões Sobre a Violência". Ao analisar o lado violento das revoluções à maneira de Marx, dizia que

a força tem por objetivo impor a organização de uma certa ordem social na qual uma minoria governa, enquanto a violência tende à destruição dessa ordem. A burguesia empregou a força desde o início dos tempos modernos, enquanto o proletariado reage agora contra ela e contra o Estado pela violência. (Sorel, 2002, p. 195) 
Quanto à defesa de Sartre à violência nos processos revolucionários, esta não significou a mesma admiração que Fanon tinha por Sorel, uma das principais referências ideológicas em Condenados da Terra, e que, segundo Jacques Julliard, é o autor de uma das mais belas definições da filosofia: a filosofia como "o reconhecimento dos abismos" (Sorel, 2002, p. 195). Sartre considerava Sorel um fascista que escrevia "lenglengas", diferente de Fanon que, sem desprezar Marx, admirava também Sorel, por lhe oferecer teorias que justificariam a irrupção dos colonizados contra os colonizadores. O filósofo argeliano Albert Camus, que era acusado de associal, certa vez ironizou o comprometimento filosófico sartriano com a ação revolucionária, dizendo que Sartre "tentava fazer história de sua poltrona." (apud Johnson, 1990). Já o jornalista Paul Johnson atenta para o fato de que, em questões de colonialismo, o que Sartre não previu, e que um homem mais sensato teria previsto, era que a violência para a qual ele dava um estímulo filosófico seria infligida pelos negros não nos brancos, mas em outros negros.(Johnson, 1990, p. 269)

De Sorel, considerado o sociólogo socialista da violência, Fanon extraiu o termo "ação direta", um termo que explicava a necessidade da ação operária durante o colapso do sistema capitalista. Sorel, que analisou profundamente o papel da violência nas relações de classe e no desenvolvimento histórico, era conhecido pelo descrédito científico e pelo lado polêmico de sua obra. Jacques Julliard lembra que, para amenizar e depreciar o impacto de sua obra, seus críticos lembravam que sua principal obra serviu de livro de cabeceira de Benito Mussolini e era bastante admirada por Antonio Gramsci, mas a veracidade dessa história nunca foi confirmada. Havia, também, uma anedota não confirmada de que os bolcheviques da antiga União Soviética e o governo fascista de Mussolini pretendiam, juntos, restaurar o seu túmulo, até então abandonado pelo governo francês (Julliard, 2002). Essa era a imagem de Sorel, uma 
referência difusa tanto para os comunistas como para os fascistas. Em sua estadia na Argélia, defendendo a libertação dos argelianos e a reconstrução da nação, Fanon não priorizava em suas análises as teorias políticas e sociais elaboradas pelos colonizadores europeus. Procurando reelaborar a idéia de nação na revolução, que seria conquistada no embate político, social, econômico e religioso do cotidiano, ele termina por defender um tipo de reconstrução através de um processo político lento e culturalmente isolado, mas com a vantagem de ser construído com base em uma ordem cultural interna, que orienta os rumos de um plano de desenvolvimento futuro.

Não entenderemos a repercussão de sua obra, se não nos reportarmos ao contexto histórico da época. Ela traz à tona as questões prementes do colonialismo, mas deixa entrever, na ótica de Gerard Chaliand, um distanciamento e uma defasagem com a história, "Os Condenados da Terra" parecendo uma obra datada, com exceção dos estudos sobre os traumatismos do colonizado, um produto de uma época e de uma corrente que, como sua vida e sua obra, é um reflexo mais lírico e mais consumado. (Chaliand, 2001, p. 294). No mais, Fanon,

salvo quando emprega seu saber e sua experiência psiquiátrica, não é antes de tudo um analista senão um poeta..(...) Uma voz messiânica com acentos sinceros, impregnada de moralismo em que se traduz sua paixão em mudar o mundo. (Chaliand, 2001, p. 306)

Nesse aspecto, são relevantes os desdobramentos históricos da guerra fria, a investida das democracias liberais contra o comunismo soviético, os combates na Indochina e no Chipre, assim como a mal sucedida intervenção britânica e francesa no Egito, após a nacionalização do Canal de Suez por Nasser, que o ocidente considerava o mentor do imperialismo árabe e defensor da Frente de Libertação Nacional Argelina (Chaliand, 2001). 


\section{Considerações Finais}

Não se pode afirmar que Sartre saiu em defesa de uma lógica das consequências, do dente por dente, do olho por olho, a lógica da vingança e do revide. Trata-se de uma violência transformadora, de uma transfiguração salvadora que resgata a dignidade e a identidade perdidas do colonizado, pois os últimos devem ser os primeiros, não podem ser senão após um afrontamento decisivo e a morte dos protagonistas (Fanon, 2001, p. 32). Antes de tudo, o filósofo lembra que o colonizado foi submetido a uma selvageria colonial que penetrou, ao longo dos anos, por suas cabeças e poros. Tal como Fanon, Sartre lembra que a descolonização é um encontro entre forças antagônicas, que jamais passa despercebida. A força é o único recurso do colonizado. Sua fúria e sua revolta contra o colonizador, portanto, é construída sob uma lógica simples e mordaz:

o aprendizado de humilhação, dor e fome, suscitará em seus corpos uma ira vulcânica, cujo poder é igual ao da pressão que se exerce sobre eles. (...) No primeiro momento da revolta, é preciso matar; abater um europeu é matar dois coelhos de uma só cajadada, é suprimir ao mesmo tempo um opressor e um oprimido: restam um homem morto e um homem livre; o sobrevivente, pela primeira vez, sente um solo nacional sob a planta dos pés. (Sartre, 1979, p. 14)

Lutar contra a colonização é lutar contra as contradições internas, entre elas as geradas pelos partidos nacionalistas e as elites intelectuais e comerciais, o que Sartre chamava de impotente burguesia de negocistas e compradores. Neste universo colonial heterogêneo, projetam-se relações complexas que unem e opõe os colonizados aos colonizadores, sendo que os primeiros se expressam por novas vias de descolonização, falsas independências e subjugação à metrópole. 
Fanon alertava sobre o papel nem sempre positivo das elites econômicas e intelectuais que, após se unirem na defesa dos interesses em comum, colocavam-se contrárias a uma ação violenta revolucionária.

A burguesia colonialista, que havia permanecido até então em seu leito de plumas, entra em ação. Introduz uma nova noção que é, falando propriamente, uma criação da situação colonial: a não violência (Fanon, 2001, p. 54).

Essa heterogeneidade colonial reflete-se também sobre os partidos políticos nacionalistas formados na colônia. Constituídos, em sua grande maioria, por pequenos artesãos e comerciantes urbanos, caracterizam-se, segundo Fanon, pelo diálogo eterno com os colonizadores e por se aproveitarem da situação colonial para defender seus próprios interesses. Fanon os descreve como reformadores, interessados apenas em discutir reformas e arranjos políticos necessários para a manutenção do sistema colonial. Para Fanon, a grande maioria desses partidos recusa a luta popular, pois acredita que a violência não seja a melhor forma de assegurar seus privilégios.

Sartre observa, entretanto, que essa fúria nem sempre é extravasada contra o colonizador. Intimidadas pela força destrutiva das metralhadoras, as tribos entrechocam-se, tendem a guerrear umas contra as outras, mantendo-se cegas ao verdadeiro inimigo. Esses nativos possuem um cérebro subdesenvolvido ou sofrem de preguiça frontal? - ironizava Fanon, em alusão aos psiquiatras do Congresso Francês.

Para o colonizado, é o momento em que os terríveis ritos religiosos vêm à tona, não mais como força de uma expressão de fé religiosa, de um universo cultural livre, mas como uma possessão mórbida da aniquilação física. Agora os transes e as danças dissipam as violências, e a alienação religiosa torna-se uma parte contínua da alienação colonial.

O que era outrora o fato religioso em sua simplicidade, uma certa comunicação do fiel com o sagrado, se transforma numa arma contra o desespero e a humilhação; os zars, as 
loas, os santos descem neles, governam-Ihes a violência e a dissipam em transes até o esgotamento. Ao mesmo tempo, esses altos personagens os protegem; isso quer dizer que os colonizados se defendem da alienação colonial voltando-se para a alienação religiosa (Sartre, 1979, p. 12).

Fanon chamava essa alienação de velhos rancores acumulados, triturações da alma e autodestruição coletiva. Isto ocorre, porque o colonizado canaliza, de forma suicida, sua revolta para a religião, liberando sua tensão muscular diante do medo da morte nas situações de perigo. Por conseguinte, advém o desprezo do colonizador, que zomba de sua irracionalidade religiosa como típica de povos inferiores. Em contrapartida, os mesmos ritos funcionam como manutenção da ordem colonial, pois a miséria e todos os males advêm do destino traçado por Deus. Temos visto que durante todo o período colonial esta violência gira no vazio, ainda que à flor da pele. A temos visto canalizada pelas descargas emocionais da dança e do transe. A temos visto esgotar-se em lutas fratricidas (Fanon, 2000, p. 51).

Para Sartre e Fanon, a explosão da raiva do colonizado faz transparecer a identidade perdida. A violência lançada contra o colonizador é impiedosa, o que causa tensões permanentes em ambos. O que se vê, é uma relação cultural que não permite mobilidade entre as culturas e nem a racionalidade de uma cultura diferente, mas a afirmação da superioridade de uma e da inferioridade de outra. O terror torna-se necessário para a emancipação progressiva. A violência adquire outro sentido, pois ela cicatriza as feridas que ela mesma fez. A violência do regime colonial e a contraviolência do colonizado se equilibram e se respondem mutuamente com uma homogeneidade recíproca extraordinária (...) Terror contra-terror, violência, contra-violência (Fanon, 2001, p. 80).

Quanto à humanidade do colonizado, eles a encontram ao lado do desespero e da morte -, ela apenas pode ser germinada com a semente da morte. Se os europeus semearam o vento, o colonizado o reverte em 
tempestade. Para Sartre, fomos homens à custa dele; ele se faz homem à nossa custa (Sartre, 1979, p. 23). Daí Fanon considerar os colonizados os escravos dos tempos modernos. A independência significaria, antes de tudo, uma reparação moral e o resgate da dignidade silenciada. A conscientização por uma causa em comum, da história coletiva e do destino nacional, contra o analfabetismo e a miséria. A violência representa a práxis absoluta. Somente ela impedirá a morte da sociedade autóctone e a petrificação dos indivíduos. É a constatação de que a liberdade somente poderá ser obtida por meios violentos, em franca luta armada, tal como na Indochina, Indonésia e no norte da África. Parafraseando Fanon, observa Sartre: A Europa pôs as patas em nossos continentes, urge golpe-álas até que ela se retire (Sartre, 1979, p. 7).

Como o próprio Sartre afirma, o sistema colonial não é um mecanismo abstrato, mas possui um lado funcional consumado pela própria realidade perversa instalada nas colônias. O sofrimento, a fome, a violência, respectivamente sentidas e praticadas contra os colonos, não são abstratos. Tudo conflui para a dominação cultural, política e para o lucro da metrópole.

Sartre, ao analisar Fanon, atenta para o fato histórico das tradições racistas francesas. No entanto, seu sentido não é mais especificado pela antropometria de Hankins, H.L. Gordon e Leaky, pelo arianismo do Conde Henri de Boulainvilliers e Arthur de Gobineau ou pelo geneticismo biológico, mas se manifesta de uma forma sutil e esmagadora na idéia de um humanismo ambíguo, que defende a liberdade, fraternidade e igualdade, ao mesmo tempo em que se proliferam discursos racistas que taxam negros como inferiores, ladrões, homicidas e sujos.

Cabe, aqui, repensar ou rever as contribuições teóricas desses dois autores à luz dos desdobramentos dos processos de independência (na maioria, sangrentos) dos países africanos, a partir do final dos anos 1950.os incêndios na capital francesa, com envolvimento de imigrantes argeli- 
nos que sobrevivem nas zonas degradadas de Paris; o aumento do contingente de desempregados dos filhos europeus dos imigrantes africanos e asiáticos que vieram das colônias francesas e inglesas; assim como a discussão da grande diversidade ou até mesmo das rivalidades étnicas existentes nas unidades africanas (Estados e Impérios), deflagradas após o processo de independência, embora já existissem essas rivalidades antes desses países africanos serem partilhados pelas principais potências européias (Grã-Bretanha, Portugal, França e Alemanha).

Como ponto de partida, Sartre desmonta o sistema colonial francês na Argélia, passo a passo. Inicialmente, vai de encontro aos neocolonialistas, indiferentes a três aspectos do problema argelino: o problema econômico, social e psicológico. O econômico é latente na falta de alimentos para nove milhões de argelinos esfomeados; o social, no descaso com a saúde e a educação dos argelinos; e, por fim, o aspecto psicológico presente no "complexo de inferioridade" perante os colonizadores. Sartre estava consciente de que o sistema colonial não iria tardar a voltar-se contra a nação colonizadora. Também estava certo sobre as fraquezas e as contradições do sistema republicano francês, quando este impediu o avanço da cultura francesa na Argélia, como no caso da alfabetização dos argelinos, sob pena de multa, ensinar a ler e escrever os escravos negros (Sartre, 1968, p. 33), assim como por conservar o que denomina incultura e crenças feudais. Em sua análise, limita-se a defender um processo de libertação revolucionário e a apoiar movimentos revolucionários de libertação, sem perceber que as fraquezas e as contradições das instituições republicanas européias poderiam expressar-se futuramente não apenas na nação colonizadora, mas nos governos africanos que obtiveram a independência. Nesse aspecto, Hannah Arendt avançou um pouco mais, pois considerava o imperialismo colonialista como um prenúncio dos regimes totalitários, das guerras civis e dos massacres étnicos futuros. Para Arendt, certos aspectos fundamentais dessa época assemelharam-se tanto aos fenômenos totalitários do século XX, 
que se poderia considerar este período como estágio preparatório para as catástrofes vindouras (Arendt, 1976, p. 15).

É importante frisar, que Sartre e Fanon foram dois intelectuais importantes no processo de descolonização - contribuição referenciada através de textos relacionados ao tema do colonialismo e também no envolvimento manifestado no engajamento político de ambas as partes. Suas contribuições passam pelo estudo das inter-relações que se estabelecem no plano do pensamento e as interconexões que ocorrem através de inúmeras razões, entre elas a existência do colonialismo e suas interconexões. Outra importante contribuição desses autores foi mostrar que o colonialismo deixou marcas nas metrópoles, e Sartre é tocado por essa realidade ao criticar o Governo francês. Sua aproximação radical com o marxismo o leva a apoiar as lutas de libertação nacional. E, por último, indo à procura da alma negra, ele tenta dotar de humanidade aqueles que foram destituídos desta condição em razão do próprio colonialismo.

\section{Sartre and the European racist humanism: a Sartrian reading of Frantz Fanon}

\section{Abstract}

Centered on Sartre's book "Colonialismo e Neocolonialismo - Situações V" and on the foreword written by philosopher Jean-Paul Sartre for Frantz Fanon's book, Les Dammés de la Terre, the present article intends to explore some Sartrian considerations on both Fanon and the French colonialism in Algeria, building upon the complexity of social relationships in colonized countries. As representatives of anticolonial thought and critics of the alienation generated by colonialism, Sartre and Fanon elaborated radical criticism on the strategies of violence, subordination and dehumanization that affected the colonized African, urged by the social reconstruction using violence, looking for a new man in his true humanity.

Keywords: Neocolonialism. Imperialism. Algeria. Violence 


\section{Referências}

ARENDT, Hannah. Imperialismo, a expansão do poder. As origens do totalitarismo: uma análise dialética. Rio de Janeiro: Editora Documentário, 1976.

CHATÊLET, François; DUHAMEL, Olivier; KOUCHNER, Evelyne Pisier. História das Idéias Políticas. Rio de Janeiro: Jorge Zahar Editor, 1985.

CHAUÍ, Marilena de Souza. Sartre (vida e obra). Coleção Os Pensadores. São Paulo: Abril Cultural, 1978. p. XII-XIII.

CONRAD, Joseph. O Coração das Trevas. Porto Alegre: L\&PM, 2009.

CUNHA, O. M. G da. Reflexões sobre biopoder e pos-colonialismo: relendo Fanon e Foucault. Mana. Rio de Janeiro, v. 8, no 1, p. 149-164, 2002.

FANON, Frantz. Los Condenados de la Terra. México: FCE, 2001.

IGLÉSIAS, Francisco. História e Ideologia. São Paulo: Editora Perspectiva, 1971.

JOHNSON, Paul. Os Intelectuais. Rio de Janeiro: Imago, 1990.

LINHARES, M. Y. A Luta Contra a Metrópole (Ásia e África: 1945-1975). São Paulo: Brasiliense, 1981.

MACUANE, José Jaime. Liberalização política e democratização na África: uma análise qualitativa. Dados, Rio de Janeiro, v. 43, n. 4, 2000.

MARX, Karl. O Manifesto Comunista. Rio de Janeiro: Paz e Terra, 1996.

MEMMI, Albert. Retrato do Colonizado Precedido Pelo Retrato do Colonizador. Rio de Janeiro: Paz e Terra, 1977.

MÉSZAROS, István. A Obra de Sartre (busca da liberdade). São Paulo: Editora Ensaio, 1991. p. 20-21.

OLIVEIRA, Waldir Freitas Oliveira. Leopold Sedar Senghor e a Negritude. Revista Afro-Ásia, 25-26, p. 409-410, 2001.

ORWELL, George. Dias na Birmânia. Rio de Janeiro: Nova Fronteira, 1983.

SAID. Edward W. Cultura e Imperialismo. São Paulo: Companhia das Letras, 1995.

SARTRE, Jean Paul. O Existencialismo é um Humanismo. Coleção Os Pensadores - Vol. 45. São Paulo: Abril Cultural, 1973.

SARTRE, Jean Paul. Reflexões sobre o racismo. São Paulo: Difusão Européia do Livro, 1968. p. 94.

. Que é a Literatura? São Paulo: Editora Ática, 1989. p. 138. 
SARTRE, Jean Paul. Prefácio. In: FANON, Frantz. Os Condenados da Terra. Rio de Janeiro: Ed. Civilização Brasileira, 1979.

. Sartre no Brasil: a conferência de Araraquara, filosofia marxista e ideologia existencialista. Rio de Janeiro: Paz e Terra; São Paulo: UNESP, 1986.

. Colonialismo e Neocolonialismo (situações V). Tempo Brasileiro: Rio de Janeiro, 1968

SOREL, George. Reflexões Sobre a Violência. São Paulo: Martins Fontes, 2002.

WEISCHEDEL, Wilhelm. A Escada dos Fundos da Filosofia. São Paulo: Angra, 1999.

Recebido: 29/03/2011

Aceite final: 13/05/2011 